\title{
Introductory Chapter
}

\section{Rural Development in the Twenty-First Century as a Global Necessity}

\author{
Rashid Solagberu Adisa \\ Department of Agricultural Extension and Rural Development, \\ University of Ilorin, Ilorin \\ Nigeria
}

\section{Introduction}

In most of the world, the areas designated as 'rural' share a number of common attributes that include overwhelming involvement in primary production (agriculture mostly) that supply food and raw materials for the larger society. In most cases, rural centers are the seed beds of national population and conservatory of pristine national culture, manpower, patriotism and tradition (Ekong, 2010). And despite also constituting the majority population in most countries of the world, the rural world is unfortunately mired in perennial poverty and backwardness. This perhaps explains why eradication of poverty is given top priority in the Millennium Development Goals (MDGs).

Although notable progress has been achieved in rural poverty reduction in many countries over the last 10-20 years, available statistics indicate that there is still much more to be done in order to arrest the trend, especially in developing countries. According to IFAD (2011), rural people constitute about $72 \%$ of the people living in extreme poverty (less than US $\$ 1.25$ per day) in these countries, down from about $80 \%$ ten years ago. About $51 \%$ of all the people in these countries live in poverty (less than US\$2/day); while $27 \%$ live in extreme poverty. Absolute poverty levels are generally low in the developed countries. For instance, about 37 out of 42 European countries have less than $2 \%$ of their population leaving in poverty (<US\$2), and rural poverty is virtually non-existent in EU and northern Europe (FAO, 2009, IFAD, 2009). Hence the onus is on the developing world to find their way out of poverty and curtail its effects on the well-being of their citizens by striving towards the attainment of the MDGs.

But how can developing countries attain the MDGs? Several scholars, agencies and world bodies have turned out useful frameworks for the mitigation of rural poverty in particular and achievement of the MDGs generally. Most of these frameworks emphasized the rural development process as being a veritable option (Bage, 2004; IFAD, 2005; Avila and Gasperini, 2005; and Rural 21, 2010). The goals of the MDGs are all important items in the rural development agenda of developing countries. It is thus expedient for rural development issues, policy and practices to take priority position in intellectual discourse among researchers and other stakeholders.

The purpose of this chapter is to introduce this book by presenting a general overview on rural development. By so doing, the chapter discusses the 'rural' concept and examines 
what is meant by 'rural development' - its importance and indicators. Furthermore the chapter looks at the determinants of rural development. Finally suggestions are offered on how to enhance the rural development process in developing countries.

\section{What is 'rural'?}

It is not surprising that the term 'rural' does not have a conventional definition, unlike 'poverty line' whose definition has been made easier by the World Bank (although some countries still have their own poverty benchmarks). While 'poverty' or 'poverty line' could be easily monetized, 'rural' or 'rurality' cannot. This thus makes it expedient for each country to have its own rural threshold, using its self-determined criteria. The term rural evades consensual definition to the extent that even within some countries, there are deferring definitions of 'rural'. For instance in the US, the 'three most common Federal definitions of rural' are those by Department of Commerce's Bureau of the Census based on the 2000 census criteria, that of the White House's Office of Management and Budget (OMB), and that of the Department of Agriculture's Economic Research Service USDA-ERS (Reynnells and John, 2008). In essence, rural could be defined in varying contexts depending on where and what criteria are used. Using some sociologically idealized models of differentiation, Ekong (2010) identified what was referred to as 'very general' differences in the rural-urban typology:

1. Size of place; rural communities tend to be generally smaller in size of area inhabited than urban communities

2. Population density and composition: number of inhabitants per unit area of land in rural communities is always smaller than for urban centers. Rural populations also tend to be less heterogeneous than urban populations.

3. Closeness to nature: rural environment permits greater and more direct closeness to physical environmental elements such as soil, wind, radiation, parasites and microorganisms.

4. Occupation: farming and other primary production activities are generally the major occupations in rural communities, unlike urban centers where organization, commerce and industry take the centre stage.

5. Cultural simplicity: complex culture, high fashion, music and literature are more associated with urban areas than rural ones.

6. Social interaction: primary group contacts form the main feature of social interaction in rural areas, while secondary contacts define most interactions in urban centers.

7. Social stratification: there are generally fewer social classes in rural areas than urban areas.

8. Social mobility: urban dwellers often move more rapidly from one social stratum to the other than their rural counterparts.

9. Social differentiation: rural areas tend to have very little division of labour and specialization and are thus made up of several similar independent units, unlike urban centers.

10. Social control: there is usually greater internalization of societal values and norms I rural areas, thereby leading to higher levels of social control than in urban centers which relies more on formal institutions.

11. Levels and standards of living: although this is not true for all places and periods, urban centers, due to the presence of a variety of infrastructures, goods, and services 
tend to offer higher levels of living than rural centers. Especially in developing countries, urban centers tend to offer higher standards of living due to better housing, education, health and communication facilities.

The above differences, according to Ekong (2010) are extremities in the rural-urban divide and do not exclusively typify any real-life communities. Indeed, all the listed items cannot be true for all rural areas around the world. They are mostly true for rural area in developing countries. For instance, while most rural areas across the developing world remain typically agrarian, in the US, the rural economy has become diverse and is no longer dominated by agriculture because less than $10 \%$ of rural populace lives on farming (USDA, 2006). It should however be noted that because the population criterion is the easiest and perhaps most practical one, most nations use it to delineate rural-urban thresholds. For instance, any community inhabited by less than 5000 people was deemed rural in Nigeria based on the 1953 census. But 2006 Census classifies a rural area as having less than 20000 inhabitants. Rural-urban thresholds vary from time to time and from one nation to another. Sweden and Denmark perhaps have the lowest urban threshold of 200 people. In South Africa, a population below 500 is rural, while in Australia and Canada a population of 1000 and below is regarded as rural. Mexico and the US classify a population of below 25000 as rural; while in Japan, a population below 30000 is rural (Ekong, 2010 citing several sources).

Ashley and Maxwell (2001) defines 'rural' as constituting a 'space where human settlement and infrastructure occupy only small patches of the landscape, most of which is dominated by fields, pastures, woods, water, mountains and deserts'; but conceded that the term 'rural' is ambiguous and echoed IFAD (2001) submission that 'national distinctions between rural and urban are arbitrary and varied'.

\section{What is rural development?}

There is neither a shortage of definitions nor a single conventional definition or 'narrative' of - or prescription - on rural development (Maxwell, Urey, and Ashley, 2001). According to van der Ploeg (1998), rural development consists of a 'balance of changing and stable elements' and that continuity and change have always characterized rural development. In other words, rural development must be conceptualized in both contexts in order to have a 'balanced' and practical definition. Rural development must consist of activities that address both elements. Just as van der Ploeg (1998) observed, the 'changing' elements in the study of rural development continue to attract more attention than the 'stable' elements. Maxwell et al illustrated the changing rural development scenario by listing a number of occurrences that illustrated the changing contexts (Table 1).

Despite the above changing contexts, the necessity for greater and deliberate efforts targeting development of rural areas and their inhabitants has continued growing, especially in Africa and other developing countries.

Before the 1970s, rural development was seen to be synonymous with agricultural development. Rural development, defined in the 1980s by the World Bank as a strategy designed to improve the economic and social life of the rural poor, has since been variously defined. For instance the USDA defines it as improvement in the overall rural community conditions, including economic and other quality of life considerations such as environment, health, infrastructure, and housing' (USDA 2006). Apart from the changing context of rural 


\begin{tabular}{|c|c|}
\hline Changing context & Illustrative Data \\
\hline Diversification is taking place in rural incomes & $\begin{array}{l}\text { Studies for Africa show a range of } 15 \text { to } 93 \% \\
\text { reliance on non-farm income (WDR). }\end{array}$ \\
\hline More of the poor are in low potential areas & $\begin{array}{l}66 \% \text { of the rural poor live in less favored area } \\
\text { (IFPRI). }\end{array}$ \\
\hline There are growing environmental concerns & $\begin{array}{l}\text { Loss of } 2 \text { billion hectares of land to degradation } \\
\text { since } 1945 \text { (Conway) }\end{array}$ \\
\hline $\begin{array}{l}\text { Changing geographical distribution of poverty } \\
\text { and underdevelopment }\end{array}$ & $\begin{array}{l}23 \% \text { of Africans fail to reach age } 40 \text { compared } 8 \% \\
\text { of East Asians (UNDP) }\end{array}$ \\
\hline HIV/AIDS is having dramatic impact in SSA & $\begin{array}{l}\text { Life expectancy has fallen by } 9 \text { and } 6 \text { years in } \\
\text { Botswana and Zambia (UN) }\end{array}$ \\
\hline The share of population in rural area is falling & $\begin{array}{l}\text { by } 203550 \% \text { of the world's population would live } \\
\text { in cities (IFPPRI) }\end{array}$ \\
\hline The importance of agriculture is declining & $\begin{array}{l}\text { Agriculture would account for less than } 10 \% \text { GDP } \\
\text { of developing countries in } 2020 \text { (IFPRI) }\end{array}$ \\
\hline $\begin{array}{l}\text { Urbanization and rising income are changing the } \\
\text { pattern of food demand }\end{array}$ & $\begin{array}{l}\text { Milk demand would rise by } 15 \text { times in } 2020 \\
\text { (IFPRI) }\end{array}$ \\
\hline The world economy is increasingly globalized & $\begin{array}{l}\text { international trade has grown } 2-3 \text { times as global } \\
\text { value added in the last decade (WB) }\end{array}$ \\
\hline International trade expansion is not uniform & $\begin{array}{l}\text { Africa's share of world exports fell from } 11 \% \text { In } \\
1960 \text { to } 4 \% \text { in } 1998 \text { (WB) }\end{array}$ \\
\hline Access to FDI is uneven & Africa's access to FDI is only $1.9 \%$ of GDP (WB) \\
\hline $\begin{array}{l}\text { Increasing liberalization, though slowly in } \\
\text { agriculture }\end{array}$ & $\begin{array}{l}\text { Effective protection fell from } 12 \% \text { in } 1960 \text { s to } 3 \% \\
\text { in } 1990 \text { s }\end{array}$ \\
\hline
\end{tabular}

Source: Maxwell, Urey, and Ashley (2001).

Table 1. The Changing context of Rural Development

development, increasing incidence of poverty/extreme poverty and recognition of its nonincome derivative have contributed significantly to the evolution of new narratives of rural development. A major non-income need of rural people, the dearth of which contributes to their backwardness is political participation - which was used to define what is known as inclusive rural development - when combined with the pursuance of their economic and social needs. Another concept is that of integrated rural development, which favours the amalgamation of development activities in various economic sectors (agriculture, commerce, industry, etc) in the rural development process. It also includes the integration of the traditionally disadvantaged groups (such as children, the youth, women, the elderly, minorities, etc) into the rural development process.

Changing understanding of the concept of 'development' itself in relation to sustainability gave rise to the concept of sustainable development. FAO (1988) defined sustainable development as: "the management and conservation of the natural resources base and the orientation of technological and institutional change in such a manner as to ensure the attainment and continued satisfaction of human needs for present and future generations. Such sustainable development in the agriculture, forestry and fisheries sectors conserves land, water, plant and animal genetic resources, is environmentally non-degrading, technically appropriate, economically viable and socially acceptable." According to Avila and Gasperini (2005), sustainable rural development is understood as a process of constant 
change and transformation of the rural areas, encompassing a wide scope of processes and programmes such as:

- Enhancement of governance at the local, district and provincial levels, including linkages with the private sector, civil society and government line agencies.

- Development of productive sectors: agriculture, non-agricultural industry, mining, tourism, natural resources, environmental management, etc.

- Development of institutions and their capacities in key areas, i.e. education and training, health, research and extension, marketing, savings and credit, environment, transportation, etc.

- Development of rural infrastructure for roads, electricity, telecommunications, housing, water, sanitation, etc.

Contemporary 'narratives', 'definitions' or 'prescriptions' concerning rural development characteristically tend to address everything that affects rural people and the quality of their life as entities and as integral members of the larger society and, indeed, the world.

\section{Rural development indicators}

Because the 'term' rural has many features and that the concept of 'rural development' is also a multi-dimensional concept, it is impossible to have a single benchmark that would describe rural situation and trends. Several sets of rural indicators and rural development indicators have been put forward by some international organizations such as World Bank, Organization for Economic Cooperation and Development (OECD), European Union (EU), and Food and Agriculture Organization (FAO). These sets of indicators share similar background arguments and address 'rural' and 'rural development' from similar angles.

The World Bank recommends five themes from which core indicators should be selected in developing countries. The themes are: Basic socio-economic data; enabling environment for rural development; broad based economic growth for rural poverty reduction; natural resource management and biodiversity; - social well-being (education and health). Each theme consists of several indicators determined based on the issues addressed.

The World Conference on Agrarian Reforms and Rural Development (WCARRD) present a set of primary indicators focusing on six themes that is also applicable in developing countries.

The six themes, as shown in Table 2 and the selected indicators are very important in determining rurality and rural development in developing countries. The WCARRD list of primary indicators incorporates rural poverty parameters such as nutrition, health, housing, and education. However, unlike the World Bank list of indicators, WCARRD list in Table 2 did not address natural resource management and biodiversity - whose importance cannot be overlooked from sustainable rural development viewpoint.

\section{Determinants of rural development}

The pace and level of rural development is determined by a number of factors that could be social, economic, institutional, cultural, technological, natural, or technological. These factors often interact and could operate to exhibit multi-level effects on rural development, 


\section{Poverty alleviation with equity}

Income/consumption

1. Percentage of population in households with per capita income below the poverty line *

2. Percentage of income accruing to each fractile (decile/quartile) of the population *

Nutrition

3. Percentage of children aged 1-5 years in groups less than: *

$80 \%$ weight-for-age

$90 \%$ height-for-age

$80 \%$ weight-for-height

4. Percentage of under-nourished population *

Health

5. Infant and child mortality rate *

6. Percentage of the population in villages/communities with at least one health auxiliary

Education

7. Adult literacy rate *

8. Primary school enrolment and completion rates

Housing

9. Percentage of rural household with specified housing facilities, e.g. piped water, electricity and sanitation facilities

Access to community services

10. Percentage of population living in villages/communities with access to: potable water, public health services, primary schools *

\section{Access to land, water and other natural resources}

Access to community services

11. Percentage of number and area of agricultural holdings by size groups and tenure*

12. Percentage of heads of rural households without land *

13. Average wage rate of agricultural labourers *

14. Rate of unemployment and under-employment

15. Percentage of landless agricultural labourers to the population economically active in agriculture *

III. Access to inputs, markets and services

16. Percentage of rural households receiving institutional credit

IV. Development of non-farm rural activities

17. Percentage of economically active population engaged in non-agricultural activities in the rural areas

\section{Education, training and extension}

18. Number of rural (including agricultural) extension personnel per 1,000 holdings/households.

VI. Growth rate

19. Annual rate of population growth

Note: Core Indicators are asterisked

Source: FAO

Table 2. The WCARRD list of primary indicators 
be it village, provincial, national or even global levels. The following includes some of the important factors that determine rural development:

1. Availability and efficient utilization of natural resources: Where a community is endowed with mineral and other natural resources in commercial quantities, there is a tendency for that community to experience rapid development. However, the sheer availability of natural resources without proper management of the proceeds would not bring about commensurate development. Indeed there are numerous examples of naturally endowed nations that remain under-developed, while less-endowed ones have moved higher in the development ladder as a result of efficient resource utilization.

2. Production and employment capacities: The higher the employment and production capacities of an area, the higher the income and growth it attracts. Increases in output and number of people employed enhance household welfare and drive the rural economy. Production must continue to increase, not only to satisfy increasing demand, but also because of the necessity to maintain capital stock of the rural economy's productive base.

3. Manpower and technology: Improvement in the means of production of goods and services, ceteris paribus, leads to higher and more efficient production. Use of modern and efficient means of farming for instance has demonstrated great potential in the achievement of food security. Societies that have adopted modern technological production modes have witnessed more rapid pace and higher levels of rural development than those that have not.

4. Good and responsible leadership: Competent and patriotic administration and management of national and rural resources have led to rapid transformation of many rural communities in the western world. Development would most certainly remain a pipedream as long as national and rural resources are mismanaged by wrong hands. Rural inhabitants need to not only to participate in the leadership process but must also ensure accountability and competency in leadership. Furthermore, according Avila and Gasperini (2005):

The leadership role of government is important in rural development in three key areas.

- Firstly, government must articulate long-term vision and strategy for the sustainable development of sector that is coherent, integrated, and complementary and supported by the national development vision and strategy of the country.

- Secondly, government must provide an enabling policy environment in terms of specific sectoral policies, legislation, and supply of public goods (e.g. budget priority, capacity building and education, empower women \& girls, strengthen $R \& D$, remove barrier to trade, increase effectiveness of donors, and improve the infrastructure of roads, electricity, telecommunication, irrigation and markets).

- Thirdly, government must be a key actor for leading in creating opportunities and protecting those who are poor, marginalized and vulnerable in society, by strengthening their access to land and other productive resources (e.g. land, water, technology), basic services (e.g. education, health and sanitation), productive opportunities (e.g. markets, jobs and income generation) and safety nets for those who cannot take care of themselves. At present, due to the weakness of governments, those with very limited resources depend mostly on NGOs. 
5. Basic infrastructure: Some basic infrastructures such as roads, health, water, and schools are needed to kick-start and propel rural development. The absence or dearth of these facilities has continued to perpetuate rurality and underdevelopment in Africa and other developing countries.

6. Peace and political stability: No meaningful development would take place in the absence of peace and stability. For instance Messer, Cohen and D'Costa (1998) posited that agricultural production drops by about $12 \%$ per annum in conflict areas. Developing countries need to evolve and apply effective conflict prevention and resolution mechanisms.

7. Literacy level: Development is truly a 'moving target', and one of its drivers is knowledge. There is so much knowledge on rural development strategies, technologies, capital resources, natural resources, and the commitment of stakeholders, especially the rural poor, which can be marshaled to eliminate poverty and hunger (Avila and Gasperini, 2005). When rural inhabitants are literate they would be able to decode and apply production, marketing and other useful information needed to enhance their living standards.

8. Other factors: Several other factors bordering on specific rural community characteristics were identified by Yilmat et al (2010). These are (1) geographical location,

(2) size of a village, (3) productivity of land, (4) type of land use, (5) active population,

(6) popular production areas, (7) proximity to a river, (8) housing comfort, (9) characteristics of drinking water, (10) productive fruit areas, (11) cooperativization, and

(12) social infrastructure investments.

\section{Importance of rural development}

There is a current argument that, owing to near-total modernization, globalization, increased industrialization and application of technological means in America and the rest of the western world, 'programs designed to meet the needs of rural residents are no longer necessary and no longer have an audience to serve' (Brennan, 2009). Although this argument seems logical on its face value, a deeper look at cessation of rural development programmes, anywhere in the world, portends grave global consequences. Brennan (2009) succinctly echoes the counter-arguments from extension and rural development specialists that the current scenario in the developed world even makes it more expedient to continue with rural development programmes, especially because of the new challenges occasioned by declining 'rurality' of western world's countrysides.

The world today has not reached, and perhaps may never reach a stage whereby rural development programmes become absolutely irrelevant. Rural development, because of its multidimensionality, transcends sheer availability of infrastructure, technology and industrialization. It encompasses all needs of rural inhabitants, including the enviro-cultural and psycho-social needs. According to Ackerman (2002), a study by a University of Virginia professor revealed 'that persons living in rural areas .... have a higher risk of dying in a traffic accident or being murdered by a stranger than residents of a metropolitan area. ' How do we situate this kind of new development? As observed by Ekong (2010), rural areas are considered to be safe and, indeed, places of refuge from dangers associated with urban life. But the way out is simple and it has been adopted by the developed countries: continuous rural development programming. Despite their respectable levels of advancement in human development, the developed economies of the world are still credited with elaborate rural 
development systems. Contrary to the belief in some quarters, it is however not in the interest of the developed world for developing countries to continue to grapple with pervasive underdevelopment. Therein lays another importance of rural development. The more underdeveloped Africa and other poor regions remain, the more the developed countries would need to grapple with drug and human trafficking, terrorism, immigration, transcontinental organized fraud and other related crimes. Underdevelopment and poverty in developing countries are partly responsible for breeding criminals and terrorists. A 'very rich neighbour, very poor neighbour' scenario does not augur well for global peace and progress.

Rural development would continue to be a frontline issue in global development agenda, for both traditional, well known reasons and the emerging ones. Whatever view is held on the future of rural development, it is still difficult to deny the immortal contribution of the rural environment and its people to global agriculture, food security and the perpetuation of the human race. In most developing countries, rural communities are home to majority of the citizens and still produce the bulk of the food and fibre.

Rural development is a crucial tool for combating global poverty, disease, human slavery and inequality. It not only creates a new level of self-sufficiency and satisfaction for members of a society who may have never experienced such development, but as a consequence of globalization and the new associated challenges in the developing world, rural development is more necessary and pressing than ever before (GAPS, 2007). Rural development is also important in arresting rural-urban migration that has become the bane of many developing countries. It would ensure optimum utilization of human and natural resources in rural communities and reduce pressure on already overloaded utilities in the urban centers.

It should go without saying that rural development is the essence of national development in developing countries. The kind of pleasant arguments earlier mentioned that is taking place in the West may never be witnessed this century in Africa and other poor regions of the world, going by predictions in available statistics. The pace and level of rural development in Third World countries would continue to define their overall socioeconomic development as sovereign states. Western countries got to where they are today as a result of implementation of deliberate rural development planning and programmes, among other factors. Virile rural development processes would give rise to development at national and regional levels and contribute to global progress.

\section{Toward enhancing rural development in the $21^{\mathrm{ST}}$ century}

With the setting of the MDGs in 2000, the stage was set, by implication, to give rural development a priority place in global development agenda. Lofty as the aims of the MDGs are, many developing countries are yet to fully and realistically integrate them into their national development agenda; even though they have offices devoted to the MDGs. Development of rural areas requires deliberate planning and execution of wide ranging activities and programmes that focus on the needs of the rural people. Ashley and Maxwell (2001) posit that a successful rural development strategy should:

i. Recognize the great diversity of the rural society and its institutions;

ii. Respond to past and future changes in rural areas;

iii. Be consistent with wider poverty reduction policy; 
iv. Reflect wider moves to democratic decentralization; and

v. Make case for productive sectors in rural development in order to maximize growth and reduce poverty.

The above are necessary principles that governments and rural development agencies need to bear in mind. Governments should identify the potential development resources and challenges of rural communities. Even though primary production might be the predominant livelihood alternative of rural people, there is always room for diversification. A recognition and exploitation of rural diversity or development would significantly contribute to poverty reduction. All productive sectors of the rural economy should be supported to enhance their capacities. Based on the 5 principles above, Ashley and Maxwell (2001) gave ten recommendations that are as well worthy of mention here, as they are applicable to rural development in Third World countries. A successful rural development strategy should:

1. Offer different development options to rural, peri-urban, and remote locations. No single approach fits all situations,

2. Provide livelihood-strengthening options for multi-occupational and multi-locational households. In increasingly noticeable feature of rural occupations is that household members tend to be engaged in more than one income-generating activity.

3. Put in place market institutions, with government playing key roles,

4. Combat inequalities in income and assets targets, timetables and concrete measures,

5. Demonstrate that agricultural development strategies would be compatible with natural resource management,

6. Recognize the importance of investment in infrastructure and human capital.

7. Respond to the obligation of protecting the poor with new social protection measures,

8. Propose pragmatic steps towards greater de-concentration and devolution,

9. Identify (and ensure) the place of rural development in sectoral programmes, and

10. Recognize the need for support for research.

The above is however not an automatic key to rural development in developing countries. Much more needs to be done. A crucial obstacle to development in Third World countries is corruption. According to Ogah (2006), 'Corruption in developing countries is perpetrated in the main, by their respective governments. The said governments apply incredible ingenuity in suppressing their own people with the support of developed countries'. As long as Third World leaders continue to corner the wealth of their countries with the connivance of their 'accomplices' in the developed world, the battle for rural development might continue to be a lost battle. When corruption and mismanagement of public funds are brought to the barest minimum, an enabling environment would be created for economic progress and global peace (Ogah, 2006). The role of the developed world and the international community in the rural development process of Third World cannot be overlooked. From trade liberalization that favours goods and services produced in the Third World to increased cooperation and contributions towards the entrenchment of responsible and accountable leadership, the developed world owes their developing counterpart much more. Foreign direct investment and aid to developing countries should favour activities and programmes relating to rural development.

Since rural development is a common necessity, regional and sub-regional state organizations in the Third World should take a cue from the EU by formulating and implementing a 
common rural development policy. Such a policy would, like in EU, help 'to achieve valuable goals for countryside and for the people who live and work there.' Poverty and underdevelopment are common problems of developing countries and could be combated more effectively when the countries come together at regional and continental levels.

\section{Conclusion}

This chapter is meant to provide a general overview of rural development. It discussed the 'rural' and 'rural development' concepts as well as the determinants and importance of rural development. Importantly too, the chapter emphasizes the necessity for the world to pay more attention to the needs of the rural people. The quality of their life should concern the rest of the world not only because of their conditions are pitiable and have potential global negative consequences, but because the future of the world is also threatened by continuing poverty and misery of the rural world.

Rural development would not be effectively pursued until everything affecting the quality of rural life is addressed. Just as it is the aim of this book, policy makers and leaders of third world countries, other world leaders and the entire international community must intensify the efforts towards addressing all issues affecting the welfare of rural areas across the globe, and strive towards the achievement of the MDGs. This would go a long way in the development of the rural world.

The twenty-first century witnesses the beginning of the first global effort to combat poverty and other derivatives of underdevelopment. It is envisaged that the generations that would inherit the world in the twenty-second century would not need to create MDGs that are similar to ours.

\section{References}

Ackerman, J. (2002). Study says rural life more risky than urban. Online graphic: contrasting indicators of urban, rural society. Available online at http:/ / post-gazette/localnews/20020506fatalitieschartsp9.asp

Avila, M. and L. Gasperini (2005). The MDGs and Sustainable Rural Development in subSaharan Africa: Challenges and Implications for Education for Rural People. Available on line at http://www.fao.org/sd/dim_kn2/kn2_051101_en.htm

Bage, L. (2004). Rural development: key to reaching the Millennium Development Goals. Available online at www.//gaps.org.au/activities/82-rural_1importance

Brennan, M. A. (2009). IFAS Community Development: The Continuing Importance of Rural Development. Gainesville: University of Florida IFAS Extension, FCS0242.

Ekong, E. E. (2010). Rural Sociology. Uyo: Dove Educational Publishers. Pp. 380-382.

European Commission, EC, (2008). Agriculture and Rural Development: Rural Development Policy 2007-2013. Available online at http:/ / ec.europa.eu/agriculture/index_en.htm

FAO (1988). FAO Council, 94th Session, 1988.

FAO (2009). Poverty in Europe. Available online at http://www.fao.org/docs/eims/upload/263500/Poverty\%20in\%20Europe1.pdf 
IFAD (2005). Achieving the MDGs: Rural Investment and Enabling Policy, Panel Discussion Paper. Available online at http://www.ifad.org/events/gc/28/panel/e.pdf

Global Aid Partnerships, GAPS, (2007). The Importance of Rural Development in Africa. Available online at http://www.gaps.org.au/activities/39-rural/82-rural_1importance

IFAD (2009). Rural Poverty Portal. Available online at http://www.ruralpovertyportal.org/web/guest/region/home/tags/europe

Messer, E; Cohen, M. and Da'Costa, J. (1998). 'Food from Peace: Breaking the link Between Conflict and Hunger'. Food, Agriculture, and The Environment Discussion Paper No 24. International Food and Population Research Institute (IFPRI). Washington DC. Available online at http:/ / www.ifpri.org/2020/dp/dp24.pdf

Ogah, G. (2006). Corruption in the Third World. Available online at http://www.gabrielogah.com/preview/serendipity/index.php?/archives/3Corruption-in-the-Third-World.html

Reynnells, L., and P. L. John (2008). What is rural? Available online at http://www.nal.usda.gov/ric/ricpubs/what_is_rural.shtml

Rural 21(2010). Rural development for Achieving MDGs. Available online at http:/ / www.rural21.com/uploads/media/R21_Rural_development_01.pdf

USDA (2006). United States Department of Agriculture-2007 Farm Bill Theme Papers Rural Development Executive Summary. Available online at http:/ / www.usda.gov/documents/Farmbill07ruraldevelopmentsum.pdf

van der Ploeg, J. (1998). Continuity and change: the continuous elements of rural development, The Hague (The Netherlands), National Council for Agricultural Research (NRLO). NRLO Report 97/42

YIlmaz, B; Dasdemir, I; Atmis, E; and Lise, W. (2010). Factors Affecting Rural Development In Turkey: Bart in Case Study. Available online at http://ideas.repec.org/a/eee/forpol/v12y2010i4p239-249.html 


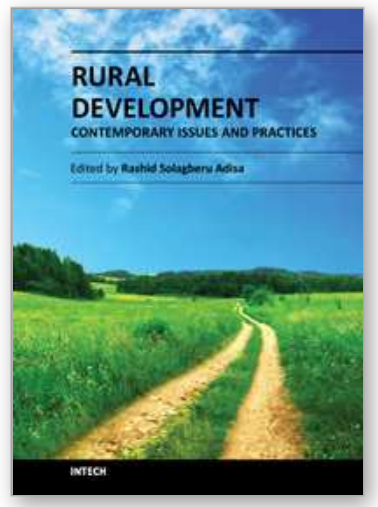

\author{
Rural Development - Contemporary Issues and Practices \\ Edited by Dr. Rashid Solagberu Adisa
}

ISBN 978-953-51-0461-2

Hard cover, 408 pages

Publisher InTech

Published online 20, April, 2012

Published in print edition April, 2012

Development of rural areas has witnessed increasing attention globally, especially over the past three to four decades. The highpoint in the renewed global interest in the development of rural people and their environment was reached with the setting of the Millennium Development Goals (MDGs) in the year 2000. All of the set goals are basically rural development goals. With less than four years to the deadline for the achievement of the MDGs, it is almost certain that the goals are far from being achieved in, especially, most developing countries for whom the MDGs were essentially set. The struggle thus continues for rural development. As long as problems of poverty, disease, illiteracy, unemployment, poor infrastructure, environmental degradation and others persist (or increase) in rural communities, better and more resultoriented solutions to perennial and emerging problems of rural communities would be required. But rural development, in spite of the variations in thresholds of rurality among nations, is not exclusively a Third World or \&lsquo;developing countries\&rsquo; process, owing to its multi-dimensionality. It is a global phenomenon that obviously requires global strategies. This book not only looks at rural development from its multidimensional perspectives, it is also a product of the experiences and expertise of distinguished scholars across the continents. Aiming to provide a comprehensive single volume that addresses salient issues and practices in rural development, the book covers themes ranging from sustainable agriculture, biodiversity conservation, strategic environmental assessment, renewable energy, rural financial resources, assessment of protected areas to statistics for rural development policy. Other subject matters covered by the book include social marginality, land use conflict, gender, cooperatives, animal health, rural marketing, information and communication technology, micro-business, and rural economic crisis. The book is thus an invaluable source of useful information on contemporary issues in rural development for researchers, policy makers, and students of rural development and other related fields.

\title{
How to reference
}

In order to correctly reference this scholarly work, feel free to copy and paste the following:

Rashid Solagberu Adisa (2012). Rural Development in the Twenty-First Century as a Global Necessity, Rural Development - Contemporary Issues and Practices, Dr. Rashid Solagberu Adisa (Ed.), ISBN: 978-953-510461-2, InTech, Available from: http://www.intechopen.com/books/rural-development-contemporary-issuesand-practices/introductory_chapter_rural_development_in_the_twenty_first_century_as_a_global_necessity

\section{INTECH}

open science | open minds 


\section{InTech Europe}

University Campus STeP Ri

Slavka Krautzeka 83/A

51000 Rijeka, Croatia

Phone: +385 (51) 770447

Fax: +385 (51) 686166

www.intechopen.com

\section{InTech China}

Unit 405, Office Block, Hotel Equatorial Shanghai

No.65, Yan An Road (West), Shanghai, 200040, China

中国上海市延安西路65号上海国际贵都大饭店办公楼 405 单元

Phone: +86-21-62489820

Fax: $+86-21-62489821$ 
(C) 2012 The Author(s). Licensee IntechOpen. This is an open access article distributed under the terms of the Creative Commons Attribution 3.0 License, which permits unrestricted use, distribution, and reproduction in any medium, provided the original work is properly cited. 